\title{
Reconciling pastoral agriculture and nature conservation: developing a co-management approach in the English uplands
}

Christopher J Short $^{1 *}$ and Janet Dwyer ${ }^{2}$

* Correspondence: cshort@glos.ac. uk

${ }^{1}$ Countryside and Community Research Institute, University of Gloucestershire, Oxstalls Campus, Gloucester GL2 9HW, United Kingdom

Full list of author information is available at the end of the article

\begin{abstract}
The article assesses the influence of the Common Agricultural Policy (CAP) on the pastoral farming systems in a National Park within the south west of England and more recent attempts to use innovative and participatory techniques to reconcile pastoral farming systems with wildlife management. The paper confirms evidence that the economic sustainability of farm businesses in the UK involved in pastoral farming is reducing, and that wildlife-orientated schemes are changing traditional farming systems in a way that might not be in the long-term interest of wildlife. The data gathered raise questions about the cost-effectiveness of the current environmental approaches, which are government-run with centrally determined prescriptions relating to the natural resource and wildlife. Drawing on the concept of co-management, an alternative approach is identified and explored with both farmers and nature conservation regulators. This approach places more emphasis upon adjusting the traditional farming system of this marginal type of farming to align with the sustainable management of a fragile ecosystem.
\end{abstract}

Keywords: Co-management, Upland, Moorland, Exmoor, Common agricultural policy, Social-ecological systems, Nature conservation, Biodiversity

\section{Background}

The English uplands are characterised by open landscapes of moorland peaks and pastoral farmed valleys with small woods and a very low proportion of cultivated land. Just over three-quarters of the uplands in England are designated landscapes: either National Parks (NPs), classed as category V protected areas using the International Union for Conservation of Nature (IUCN) definition, or Areas of Outstanding Natural Beauty (AONBs), a national protected landscapes designation (Carruthers et al. 2009). With steep slopes, poor soils and a short growing season compared to lowland England, these are marginal farming areas, traditionally managed for the extensive, grass-based production of sheep, beef and some dairy farming, and their designation as European Union (EU) Less Favoured Areas (LFA) reflects this. They are areas of great significance for biodiversity most of the higher land is classified as Natura 2000 sites, or the near-equivalent national designation of Site of Special Scientific Interest (SSSI). A long history of enclosure has left important features in the landscape, notably systems of field boundaries across the lower slopes and in the valleys, while the moorland itself remains largely undivided and much

(c) 2012 Short and Dwyer; licensee Springer. This is an Open Access article distributed under the terms of the Creative Commons Attribution License (http://creativecommons.org/licenses/by/2.0), which permits unrestricted use, distribution, and reproduction in any medium, provided the original work is properly cited. 
of it is registered shared (or 'common') grazing (Short, 2008). Many English upland landscapes also contain valuable archaeological remains because unlike other parcels of land, the soil here has remained undisturbed. All these elements coalesce to produce some of the most valued cultural landscapes in England, with a similar pattern across the upland areas of northern Europe as outlined by Eriksson (2011).

Government policy goals for the uplands over the past three decades have shifted away from support for the use of the land primarily to generate agricultural output and support farming, towards a greater emphasis upon these areas' high environmental and amenity value (Lowe and Ward 2007; Condliffe 2009; Dwyer 2010). This move towards a multi-objective and benefit approach is in line with a global shift towards a more holistic approach to policy that seems to be focusing around the ecosystem services approach developed as part of the Millennium Ecosystem Assessment (MEA 2005) and the widely respected UK report, National Ecosystem Assessment (NEA 2011). Most upland areas within the UK also experience high levels of recreation and tourism activity. Various forms of exercise - walking, hiking, field and water sports and aerial recreation (gliding, etc.) - are common and some of these have had a major influence upon land use and management (shooting, in particular) and the rural economy. The uplands also play an essential role in providing much of the population with clean drinking water: of the total UK water supply, around 70\% is sourced from the uplands (Natural England 2011; Reed et al. 2009). Upland land management also has a strong influence on river flows and flood risk. The peat soils in the uplands represent a major carbon store and offer important potential for further carbon sequestration, the South West in particular (Natural England 2010). Many uplands also offer significant potential for renewable energy generation from wind and water, in particular.

The English uplands face two significant challenges, both of which are common to marginal farming areas across the EU, as Nori and Gemini (2011) outline in relation to the more recent reforms of the Common Agricultural Policy (CAP). Firstly, farming incomes are low, and heavily dependent upon the support provided by the CAP. The second major challenge is to halt the environmental decline. In environmental terms, the English uplands have suffered declines in the extent and quality of important habitats and species since the 1940s, and particularly in the decades between 1970 and 2000.

This article firstly outlines the traditional pastoral farming system that has shaped the English upland landscape for the past 500 hundred years and then introduces the principles of co-management as it is developing in the UK. The article then assesses how the CAP and in particular the environmental schemes are impacting on wildlife. To illustrate this, the article uses findings from a recent study within Exmoor National Park in the south west of England (see Figure 1). The final section assesses the suitability of the concept of co-management as a possible approach that will reconcile differences between the pastoral system and the need to stem environmental decline in upland areas.

\section{Overview of the English upland pastoral system and study area}

Longstanding English upland farming systems comprise sheep and beef-rearing enterprises which make use of the varied contours and conditions found in these landscapes. The exposed moorland and enclosed land on the higher slopes is mainly used to rear 


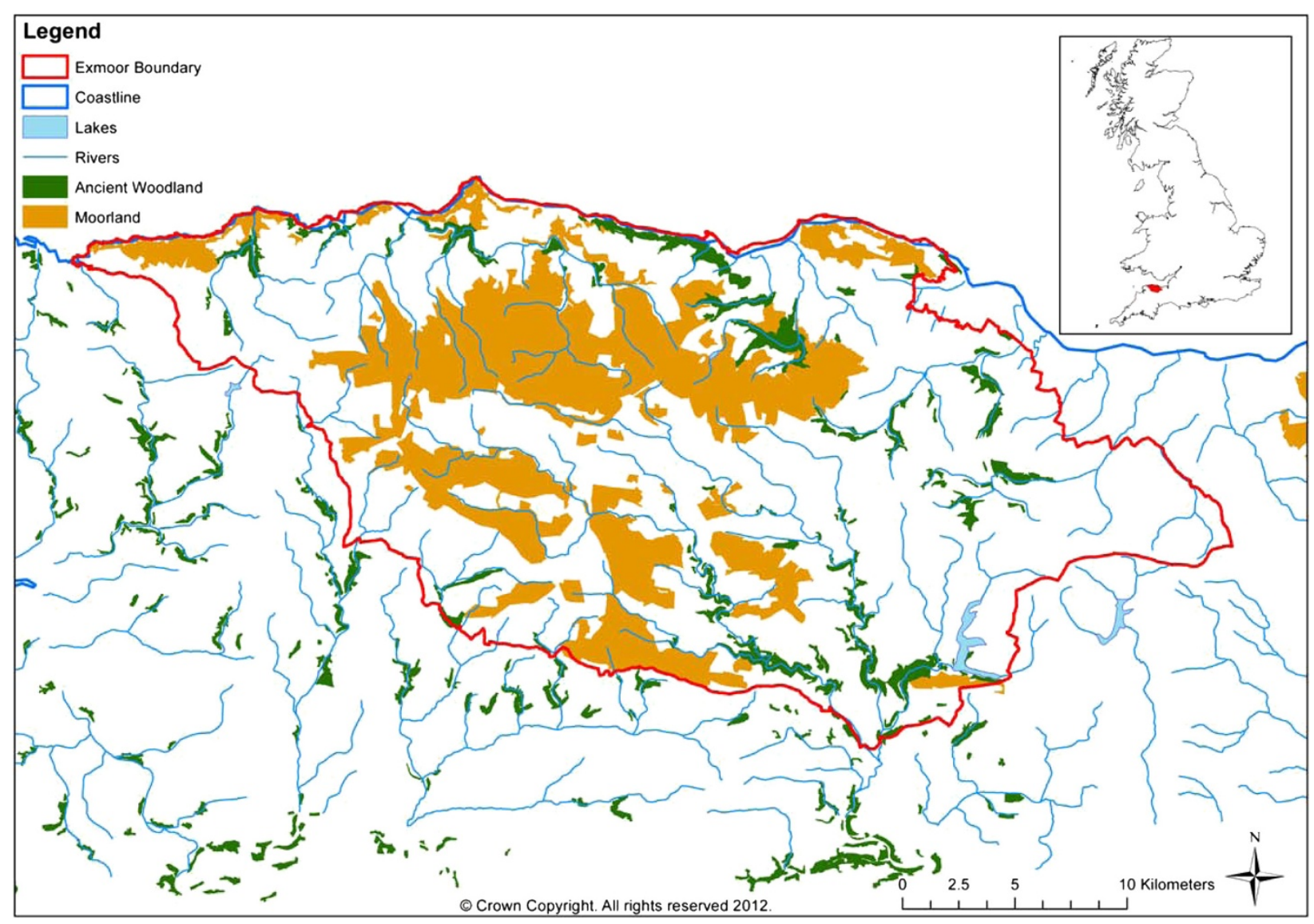

Figure 1 Exmoor National Park in the south west of England. 
breeding stock - hardy hill breeds of sheep and cattle, and on Exmoor, native ponies. The majority of the ewes in a hardy sheep flock are crossed with less hardy but bigger breeds to produce crossbreed flocks. Traditionally (certainly since the mid-20th century), the majority of half-hardy ewes would be sold to lowland farmers as breeding stock, and the male lambs sold as 'stores' to be fattened on lower, more productive land. If there is sufficient lower enclosed land (often called in-bye land) available, an upland farm may also run its own cross-bred flock which is more productive than the hill breeds (as measured in both lambing percentages and carcass weights).

Upland farm cattle are predominantly suckler cow herds which are used to produce beef calves. While the hardy breeding animals can graze the moor all year-round, their progeny will usually graze the hills only during the summer, and in winter they will be moved down to lower-lying pastures, prior to sale off the holding or recruitment into the breeding flock or herd, in the following year. Commonly, grazing land for these young stock was provided on upland dairy farms often located in the valley bottoms, where the milking herd was generally kept indoors through the winter.

During the 1970s and 1980s, there is evidence that a combination of market trends and CAP support payments encouraged many hill farms to increase stock numbers and the intensity of land management in these areas (Baldock et al. 2002). The market trends show a steady increase in sheep and cattle numbers, largely because the support payments were headage payments with farmers receiving payments per head for their number of breeding ewes. As Baldock et al. (2002) point out, this strongly influenced farmer behaviour and led to an increase in the number of stock grazing upland areas. By the early 1990s the major threat to biodiversity in upland areas was overgrazing by sheep and cattle (English Nature 1996). Following the 1992 CAP reforms, crosscompliance conditions were introduced on sheep and beef support payments which were specifically designed to deter overgrazing, and during the 1990s stock numbers in these areas stabilised (Baldock et al. 2002). In the same period, environmental schemes for upland farms specifically sought to reduce overgrazing of moorland, as well as encouraging a range of positive management actions, including restoring traditional field boundaries and protecting farm woodlands from damage by livestock, through fencing. However, in 2002, the government's nature conservation agency re-stated that overgrazing was one of the key issues undermining favourable status on Natura 2000 sites in England (English Nature 2002)and it was expressed again by Natural England (NE) in 2009 (NE 2009), the English government's nature conservation agency. During this study, one of the interviewees outlined the concerns of NE that the:

'Elements of the intensive livestock model of upland farming we saw in the past were an environmental disaster (high stocking rates, wetland drainage, fertiliser applications) leading to unfavourable condition on many upland SSSIs (species and habitat losses), diffuse water pollution, soil erosion and carbon loss.'

(NE adviser pers. comms. 2009)

This concern explains why many upland areas have been targeted with a variety of environmental schemes since the late 1980s, offering payments to farmers for reductions in stocking levels per hectare, notably on the moorland areas of the farm. This is matched by regulations linked to the receipt of support payments (often called cross 
compliance) to prevent severe overgrazing, and has been applied to agricultural policy support since 1991.

A pictorial representation of the interlinked use of the upland landscape in 'traditional' hill farming systems, as well as a summary of long-term trends in farm business change (c.1980-2005), is given in Figure 2.

Farming businesses in these areas have generally limited options for farm diversification, due to their distance from urban centres and markets. Nevertheless, many receive some income from non-farming activities. Whilst upland farm businesses are noted for their resilience in the face of harsh economic and environmental conditions, they can also be particularly prone to social disadvantage, as a combined result of poor access to services (CRC 2008) and for some, poor living standards. Most of them have a very strong cultural attachment to their way of life and the traditions associated with hill farming (Defra ACEO 2009). The protection of upland farming culture, such as the traditional farming system and presence of hardy upland sheep breeds, is a highly emotive issue, as Swales et al. (2004) reported in their evaluation of the uplands:

'The strength of feeling on many of the issues raised by our research is worthy of comment. One respondent said, 'We would stress the importance of the need to involve emotional aspects simply because to exclude them would ignore the 'heart' which has been pivotal to the structure of [these] rural areas for centuries." (p.29)

This article focuses on Exmoor and in particular the area of Exmoor National Park; see Figure 1. In Exmoor, the relationship between longstanding marginal farming

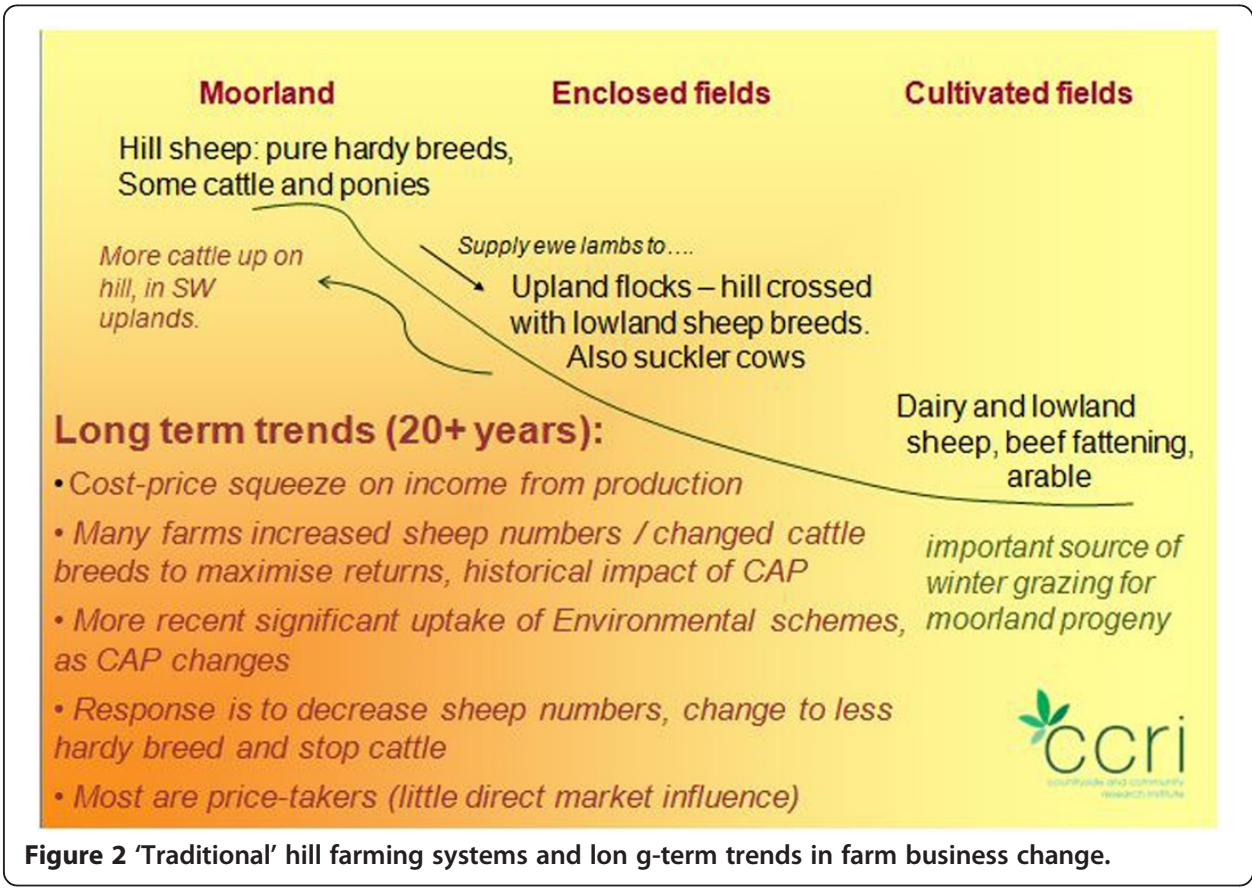


practice and the environmental qualities of these landscapes is well acknowledged - as reflected in the Exmoor National Park Management Plan (2007):

'The historical character of Exmoor is as a managed landscape, in other words there has been a relationship between man and the environment over many thousands of years. Furthermore, the flora and fauna require a mixed landscape. The significant challenge will be to work with farmers and land managers in a way that recognises that though much of the land is in commercial management, it can be sensitively managed for a variety of other benefits including high quality landscape; habitat and wildlife management; archaeology and historic buildings, and quiet enjoyment by the public. Ultimately, Exmoor National Park will only retain its special qualities with support from the people who own and manage the land.' (p.16)

Exmoor National Park supports a rich and diverse range of habitats and species. On the moorland this extends to areas of open heather and grass with upland bogs and deeply incised wooded valleys (locally called combes) blanketed in upland oak woods. Amongst the special flora and fauna are veteran trees, all species of British bats, rare lichen and bryophyte communities, notable butterfly populations, including the high brown, heath and marsh fritillary butterflies and an impressive assemblage of heathland birds. The ancient farmed landscape features small hedged fields (see Figure 3, in Exmoor these are characteristically a ditch with a bank and a beech hedge planted on top), unimproved acid grassland, narrow lanes, orchards, stone barns and farmsteads and specific breeds of livestock, namely Exmoor Horn sheep and Devon cattle.

The agricultural economy of Exmoor is dominated by hill farming, although on the better land to the north and east of Exmoor, arable crops are grown. The typical upland farms have access to a combination of open, rough moorland for grazing and enclosed

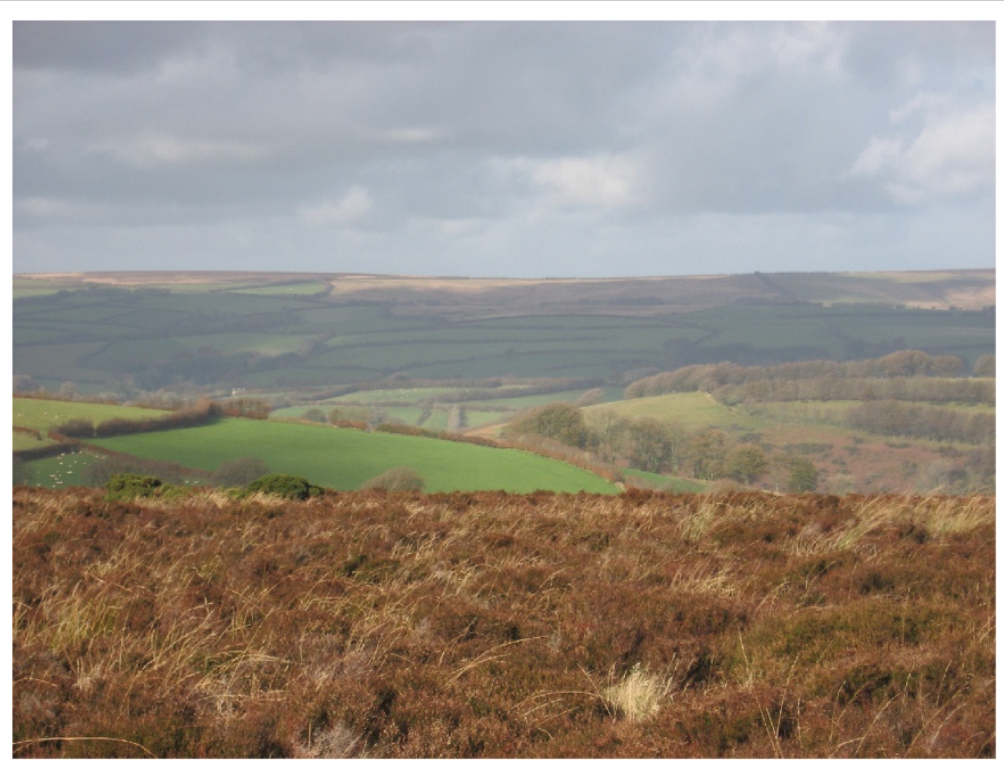

Figure 3 An ancient farmed landscape. 
pasture of varying quality where silage or hay may be cut and, rarely, root crops can be grown, for winter feed. In Exmoor, most farms are owned by the farmers themselves. In this sense the valued Exmoor landscape owes its existence to agriculture but is also threatened by recent changes to the traditional farming systems. Having outlined the traditional pastoral approach in the English uplands, the next section will look at the economic impact of recent changes in the industry.

\section{Methods}

To investigate the impact of policy, both agricultural and environmental, and the combined effect on farm businesses and land management activity on the biodiversity of the uplands, 20 in-depth interviews were undertaken, each with a detailed, selective and iterative approach which would enable causal linkages between policy design, delivery and farming systems and practices to be explored at the level of individual farm businesses. This facilitated an understanding of how farm businesses are responding to different policy and non-policy drivers, as seen in the ways in which they develop their businesses and carry out their land management. In turn, such an understanding would indicate the extent to which these strategies and practices are likely to generate and sustain the environmental and other public benefits sought by government.

The in-depth interviews were supplemented by three other stages:

1. Before the interviews took place a review was undertaken of specific sources of recent literature and data on the local context and policy history, including analysis of available farm survey datasets;

2. Following the in-depth interviews, a workshop was held for all those interviewed and also two or three local delivery agency officers, to help substantiate findings from interviews and to explore causal linkages between policies and farm changes in more detail;

3. The final stage was for feedback to be received before a refinement in the dialogue and development of policy recommendations in collaboration with those groups consulted and involved in the Exmoor.

In these terms, this research is focused upon the impact of policy as much as content; it involves deducing the impacts with the local stakeholders, in order to expose the causal linkages between policy and changes on the ground; and it is designed to enable the evaluators to be external, but working in a transparent and open way with the various groups.

The approach also reflects that used by the GEMCONBIO project, a European-based project that sought to develop new policy instruments concerning governance and management of environmental, social and economic emergencies and a process for the development of adaptation strategies (Simoncini et al. 2008:28). The GEMCONBIO project aimed to develop these guidelines using an ecosystem approach, which emphasised the need for participation and arises out of the recent Millennium Ecosystem Assessment (MEA 2005). The type of approach taken by GEMCONBIO and developed in Exmoor reflects the principles and process of co-management, as outlined by Carlsson and Berkes (2005), as 'the result of extensive deliberation and negotiation' - meaning it is very much a process rather than a fixed state. The World Bank has described co-management as a 
'decentralized approach to decision-making that involves the local users in the decisionmaking process' (The World Bank 1999:11).

Co-management has its roots in the work of Likens, Burch and others who combined social theory with ecology to develop social-ecological systems (Olssen et al. 2004) or human ecosystems (Likens 1992). These recognise the impact of human activities over time to the extent that the nature and the social are combined and deeply connected. The applied nature of this approach and the desire to change the more polarised approach of 'nature', and 'society', has led to these concepts developed further through approaches such as 'community-based conservation' (Berkes 2003) and 'adaptive management' (Jacobson et al. 2009), both, like co-management, starting from the premise that conservation and community development can be achieved in parallel. This centres on a significant shift in ecological thinking that recognises humans as part of the ecosystem and the need for participatory approaches to identify and integrate 'traditional' human activities into conservation management.

Thus the co-management concept, as outlined by Carlsson and Berkes (2005), fits with the attempted reconciliation of the pastoralist system used by farmers in the uplands and wildlife management. Carlsson and Berkes suggest six steps as a means of developing a co-management approach, which involve (adapted from Carlsson and Berkes 2005:73-4):

- Defining the sociological system - i.e. identifying the group, community or system to assess and determining its various stakeholders and structure(s);

- Mapping the essential tasks and key issues - what activities are performed, who makes this decision and how are these decisions related and problems resolved;

- Clarifying the participants - who is involved, directly or indirectly in the activities and decisions identified in the mapping process;

- Analysing linkages - what are the connections between these activities within the area and their impact on neighbouring systems and areas;

- Evaluating capacity needs - a comprehensive review of the institutional arrangements and the capacity of the various stakeholders;

- Developing a way forward - involving all stakeholders in shaping an adaptive process that provides an integrated process for future decision-making.

They conclude that by applying such a co-management approach, underpinned by these six steps, 'power sharing will typically be regarded as the end result of a collaborative problem solving process rather than a starting point of a co-management decision-making process' (Carlsson and Berkes 2005:74). These is in stark contrast to conventional resource management approaches as outlined by Berkes et al. (2000), which are characterised by rules and regulations, established by a central agency and enforced by agents with little connection to the resource. It is this distinction between the two approaches and the perceived notion that agriculture and wildlife policy have become polarised that suggests that co-management might provide a way forward for the uplands. The next section analyses existing datasets in order to grasp the main challenges to upland farm businesses in England, and more specifically the south west. 


\section{Analysis of existing data on farm businesses in the English uplands}

Under the 2005 reforms to the CAP, England opted to separate all direct payments; that is the support paid to farmers based on area of crops and number of livestock, a process often referred to as 'decoupling' payments from production, from 1 January 2005. In addition, whilst entitlements to this support were initially (in 2005) allocated to each farm on a historic basis (thus reflecting past productivity), the Department of Environment, Food and Rural Affairs (Defra) introduced a system which will gradually reduce the proportion of payments made on a historic basis and replace this with payments made on a standard area basis, in a phased way over eight years, up to 2013. For the area payment, there are three classes of land for which different payment rates per hectare apply:

- The lowest rate is paid on moorland, which in 2009 was around \$40/ha;

- A higher payment applies on LFA land which is classified as 'Severely Disadvantaged Area' (SDA), \$230/ha, and

- A uniform, higher payment applies to all other farmland in England which falls outside these two categories, including upland areas formerly designated as 'Disadvantaged Area' within the LFA, \$280/ha (figures from Defra, as at November 2009).

There is widespread recognition that farming incomes in the English uplands are low, and heavily dependent upon the support secured through the CAP. The Farm Business Survey, which collects data from across the UK, shows that in 2007, the most marginal areas in England earned 50\% of their total revenue (output) from crop and livestock farming activities with $42 \%$ coming in various forms of support provided by the CAP (Franks et al. 2008). The balance of revenues was earned from non-farming or diversification activities. In 2006-7 the average LFA farm was losing money on its commercial output, on average this amounted to $-\$ 25,520$ in 'Farm Business Income' (meaning a loss rather than a profit before accounting for family labour). However, revenues earned from the CAP under the single farm payment, environmental schemes and diversification offset the losses in farm business Income (sale of products minus costs such as fuel and feed), to generate a net average return of $\$ 27,160$. Nevertheless, this income does not include the cost of unpaid labour, provided mainly by the farm family. As with many average financial figures, there is substantial variation amongst farms in terms of their commercial performance, but it is clear that many upland farms would struggle to continue as commercial businesses without continued public support (Franks et al. 2008).

The figures for the south west uplands suggest that average farm business income is projected to fall by $34 \%$ because of the SPS changes, possibly rising to a cut of $64 \%$ for the larger 'mixed grazing livestock' farms between 2008 and 2012 (Turner et al. 2008). Under the worst case scenario the cut in income would be $43 \%$ on average and $76 \%$ for the mixed grazing livestock farm (the type of farm most likely to provide grazing on moorland). A recent Defra survey which drew responses from a large and statistically representative sample of over 1,000 upland farms across England, has provided information on how farmers have been adapting their farm management to current economic and other conditions, since the implementation of full decoupling in 2005 (Defra ACEO 2009). 
In the last four years, $36 \%$ of upland farmers have reduced or stopped grazing on moorland, which is the highest most marginal land in the uplands. The most common reasons given were due to environmental schemes (61\%) and the poor financial return of upland livestock (38\%). These figures suggest that farmers have responded significantly to the incentives of environmental schemes to reduce overgrazing on moorland areas, but indicate that wider economic factors have also reduced the business incentive to graze moorland. While the changes in CAP support outlined above are important, consistently weak market prices up to 2007 (Gaskell et al. 2008) may also be relevant. Such reductions may also hinder farm businesses responding when market conditions improve, as they have since 2009.

Within Exmoor analysis of farm survey data (Defra 2011) over a ten-year trend (2000-09) highlights the decrease in stock numbers; especially sheep (see Figure 4).

The table shows a reduction of about just under 10,000 in the total sheep flock across Exmoor in the 10 year period. Of these 5,000 are ewes. The slightly lower reduction in lambs points to a marginal increase in lambing percentages, which would suggest a move to less hardy and more productive breeds. The cattle numbers are already low but indicate a small reduction over the same period.

Other figures for Exmoor also indicate a shift from full-time to part-time farmers and a decline in the number of medium-sized 50-100 ha holdings, with increases in the numbers of very small and larger holdings. As farms enlarge and medium-sized units disappear, this reduces the availability of 'starter units' for new entrants. The Defra survey (Defra ACEO 2009) across the whole of England found that just over a fifth of upland farmers expect that their business will not continue beyond the next five years. These are largely farmers aged over 55 and those less likely to have a son or daughter to take over the farm business. This is within a sector of the industry and that is classically quite static, with almost two thirds of farms (64\%) being long established family businesses and $25 \%$ being first generation family farms. The same survey found that on $37 \%$ of upland farm businesses succession is secured (almost entirely within the family).

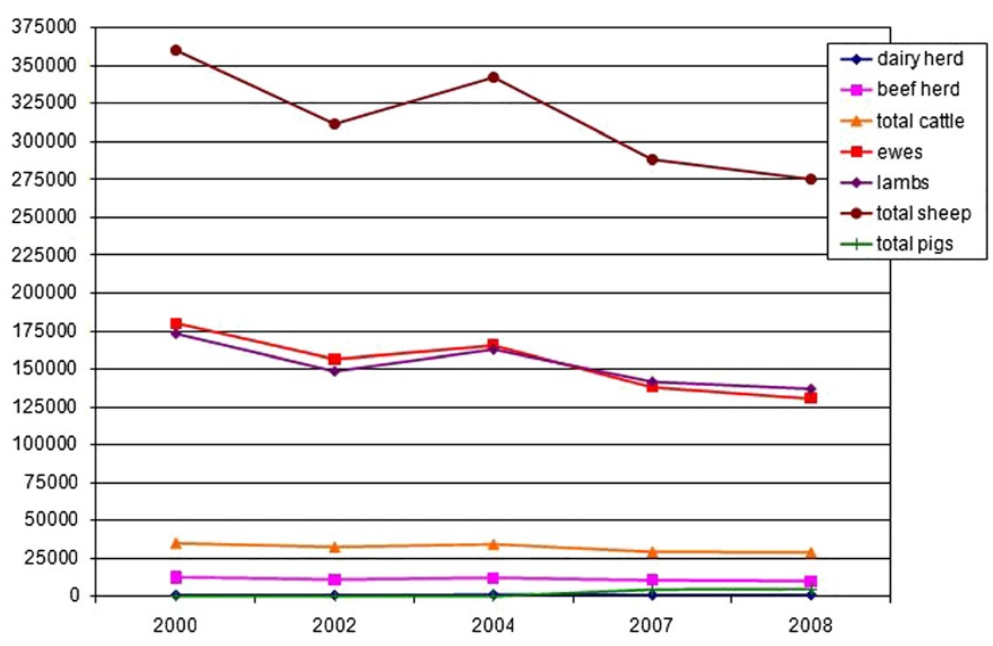

(Source Defra 2011)

Figure 4 Exmoor stock numbers from 2000 to 2008. 
These figures suggest a community which is uncertain about its future viability and may be having difficulty attracting the next generation into farming.

The next section looks in detail at how farmers have been responding to these challenges and the impact of the policy mechanisms introduced to alleviate them.

\section{How upland farmers are responding to these challenges}

The 20 in-depth interviews were undertaken with a sample that include a range of farm sizes, types/systems, tenures and family/social situations that reflected Exmoor as a whole, according to the research identified through literature review. The interview used a semi-structured format with questions designed to review a ten-year period of farm changes and a more detailed evaluation of the impact of existing and past policies. At the end of the interview, views on likely future change, concerns and aspirations were gathered. The interviews all took between 1.5 and 2.5 hours, and all took place on the farm (face-to-face). This was followed by a workshop to which all of the farmers were invited and it is at this stage that a new framework reflecting the co-management approach was discussed.

The interviews revealed four distinct, but often overlapping, strategies of farm business development since 2000:

- Farm enlargement, in order to maintain or increase income; some farmers interviewed had doubled or trebled the size of their farms.

- Simplifying the farm business by ceasing one enterprise, such as dairy or beef production, often because they require more labour costs than sheep production.

- Supplementing or subsidising the farm income with income earned from nonfarming or off-farm activities.

- Adjusting the farming system in response to environmental schemes and/or the introduction of decouple payments in 2005, which removed the link between farm support and stock numbers.

Enlargement was a strategy used by just over half of those interviewed; three farms doubled or trebled in size and a further eight had made more modest increases. None had decreased the area they farmed. In most cases, additional land has been bought or rented as it has come available nearby, with farmers seeing it as an investment (small increases) or as a necessity to continue farming and plan for succession. One farmer explained how when the succession on their farm was agreed about ten years ago, the family calculated that it would need about 400 hectares to support each family member, so they needed more land. The family therefore increased the farm area in 2000 (by 117 ha), 2002 (50 ha), 2004 (45 ha) and in 2008 (490 ha). They also increased stock, trebling sheep and cattle numbers. However, as some family farms expand in order to meet the needs of succession, others with no successor cease trading, thereby providing the land for such transactions. The most common result of this adjustment is for fixed costs to be spread more thinly across a larger unit, gaining economies of scale, but also stretching the management capability of the family.

Simplifying their business was a strategy of five of the 20 by ceasing one enterprise type among the mix. In the case of dairying, one had left this enterprise and turned to 
non-farming uses of the land while the other had decided to focus exclusively on the dairy. In other cases, labour costs are a driver: one farm ceased beef production because cattle require more labour than sheep but on another the farmer felt the reverse was the case and reduced his flock to a small pedigree flock and doubled cattle numbers. The other reasons given for enterprise changes were to meet environmental scheme requirements (discussed below) and to reflect the impact of the Single Payment Scheme, and in one case, the impact of deciding to convert to organic production, which meant the land could not carry so many livestock.

Supplementing or subsidising the farm income with income earned from non-farming or off-farm activities has been a common strategy that started before 2000. Commonly, this involves the spouse of the main farmer and/or son having a job outside farming or the main farmer having a second income. For example within the sample, a spouse has another job off the farm: some do farm recording; others work in project management, teaching and the leisure industry. In several cases, the principal farmer had another parttime job which was more closely linked to farming: two are farm contractors providing services for neighbouring farms; two others are farm business consultants offering professional advice and help with form-filling; and at least two businesses make some money from shooting. At least four farms have income from holiday accommodation including bed and breakfast, camping and renting cottages. Thus the overwhelming majority of interviewees derive a share of their total household income from sources other than the farm itself. However, this tended not to involve any of those who had significantly increased the size of the farm or specialised into particular enterprises, suggesting this absorbed the family labour on the farm.

All of the farmers had entered the farm into agri-environment schemes during the preceding 20 years. All farms had also been affected by the introduction of the Single Farm Payment, the decoupled support introduced in 2005, which, as explained earlier, removed the link between farm support and stock numbers. In response to these two factors, many farmers had adjusted the farming system. For others, a move to fewer hardy hill stock has been a response to the payment opportunities presented by agrienvironment schemes as reductions in stocking levels per hectare, notably on the moorland areas of the farm, are required under the schemes. The reductions have been significant with three farmers no longer grazing the moor and a further four reducing their livestock by at least half. As one farmer put it 'having a few stock on the moor, now, it just isn't worth it - labour or stock-quality wise'. Decoupling, and the introduction of an area-based payment that is not linked to production, has also increased the relative attractiveness of this option. In almost half of all interview cases, the consequence of this has been a significant change in the emphasis of the overall land management.

As far as grazing the moorland was concerned at least four farmers had given up their pure bred hill sheep flocks while all others are spreading their sheep flock more thinly across larger areas of land. One of the farmers noted that the population of the local bred of sheep, the pure-bred Exmoor Horns, had fallen from thousands to just hundreds in about 20 years as a result of this change. As the number of sheep grazing the moors (most of them common grazings), decreases it becomes harder to gather the livestock at key times of the year, and this is exacerbated by the reduced number of people available to undertake the task. However, while the number of potential and 
actual graziers has decreased there has been a revival in the social structure associated with commons, largely because the environmental schemes require a constituted committee of rightsholders. In many cases such gatherings had hardly been functioning but this requirement has led to an increased sense of social cohesion, collective management and communication between the remaining farmers.

The result of this adjustment to the farming system is that the moorland is no longer an integral part of the commercial farming system and is consequently managed minimally, and largely for what the farmers see as 'cosmetic' purposes, as required under agri-environment agreements (from a different perspective, this management is clearly for environmental purposes). The means of implementing the required management is, in some cases, the use of extensive, hardy cattle or Exmoor ponies to graze the moor, supporting the separation of this land in management terms. The impact on the lower slopes is to have more intensive management in order to carry the main body of income-generating livestock production, further fragmenting the traditional system that linked the moors and the lower slopes.

When compared to the traditional upland farming model described earlier in Figure 2 and outlined in Figure 5, the combination of management strategies described above appears to have led to an increased degree of fragmentation of farming systems across the landscape, so that the tiered system, in which the use of the hill, the in-bye and the lower more fertile valleys was functionally linked throughout the year, has broken down on many of the farms investigated.

\section{Impacts of farming system changes on environment and wildlife}

In environmental terms these changes to the traditional farming system have produced a mix of negative and positive impacts in quite a short time. There is some improvement on

\section{Analysing Farming systems: shifts \& rationales}

Moor

In-bye/ in-take

‘lowland' DA

Hill sheep, cattle, ponies:

Pure hardy breeds

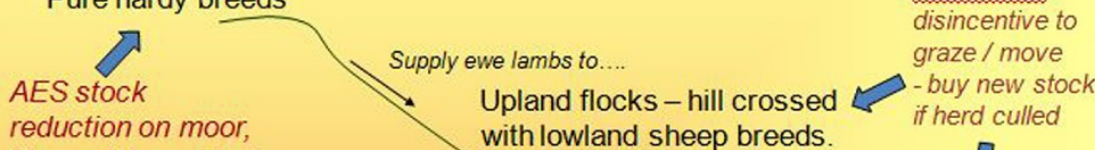

Support decoupled

3 strategies to maintain income Also suckler cows

- forget the hill flock, put some 'cosmetic'grazers on the hill, intensify on the in-take and in-bye and fatten more, to seek added-value

- enlarge significantly $(3 x)$ - removes smaller starterholdings, spreads fixed costs, stretches labour

- find anotherjob / enterprise to subsidise the farm - requires time, capital and business skills

Dairy disappearing, nowhere to send lambs over winter

Dairy and lowland sheep, beef fattening,
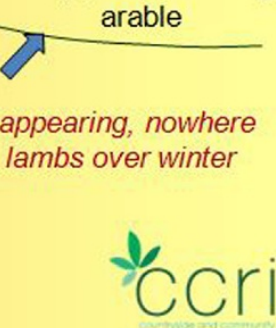

Figure 5 Traditional upland farming model and strategies to maintain income. 
the moors that had in the past been overgrazed, and the most recent data from supports this (NE 2011). However, should these lower stocking rates continue, scrub cover such as gorse, will continue to increase, raising the potential fire risk. As the lower slopes are farmed more intensively, the management differentiation between the moors and the enclosed land becomes wider. This harms the diversity and connections between different habitats that are key to many characteristic upland species, notably birds (Boatman et al. 2008).

Farmers' feelings about these changes vary. There is concern about a perceived decline in traditional hill management. There is also a feeling that this process has been pushed too far, by a combination of environmental policy and commercial factors.

With regards to the environmental schemes, the balance of opinion is sympathetic, although most farmers admit that a key reason for joining these schemes is financial and to maintain incomes. Nevertheless, there is some resentment that the top-down prescribed management is in some ways too restricted and lacks flexibility. Many claimed that whilst initial destocking had brought some benefits for heather and other upland habitat, continued management with only very low levels of sheep or cattle grazing was now leading to farmers' impoverishment. Some suggested that there was a lack of understanding that reversing business decisions about stock numbers would not be easy, for farmers. As one farmer said 'you can't keep your stock waiting on a washing line and drop them down as and when required.'

Several farmers were concerned about the prescriptions, especially stocking rates, and the impact of not meeting the requirements (minimum or maximum), noted that 'if we don't hit their targets then they might want their money back. Crucially they felt these issues, and the impact of the environmental scheme had not been openly discussed, as these quotes show.

The farm has become more extensive in the past 10 years, the hay quantity is down on the land in the scheme, but plant species are up: it looks rubbish to me and the stock don't like it, but NE [Natural England] love it and say it is species-rich now.

A closer working relationship between the farmer and the scheme adviser is needed. Farmers are scared of not doing things right by the prescriptions of the schemes; we also have other knowledge to offer.

I wish I could walk the fell [a local term for moor] and the areas we manage with the [environmental scheme] officer then we'd have a better and closer working relationship.

Farmers are adaptable but agencies seem to take the view 'we have the money so you have to listen to us'. A new approach is needed which is more farmer-focused.

This desire of farmers to be part of the solution in the uplands, rather than a 'service provider' for the national environmental agency, was explored further in the workshop that followed the interviews. About half of the interviewed farmers attended this workshop which was also attended by the local environmental scheme officer and the national park officer. In this setting the farmers were prepared to discuss what a new scheme might include, such as the creation of new habitats, management of landscape features, mechanisms for developing mutual skills in farming and environmental management. The framework for such a new scheme was to be based around discussions, a collective 
approach and a business focus that included an audit of each farm to show their biodiversity and landscape assets and potential. The emphasis here was that if the scheme could be locally developed, then they would be more willing to go further in the environmental management. As these three farmers put it:

'We are looking for one scheme which can be tailored down to individual farms, making the link with their business aims and plans.'

'The old schemes were manufactured nationally, we need a local situation.'

'A whole farm plan that covers all aspects is better than numerous separate agreements or schemes: a holistic plan that does not single out bits but sets objectives that farms can fit into and secure funding from.'

The tenor of the discussion clearly indicates a willingness among those present to work with the government agencies to develop a new approach. This would be more flexible, enabling a package of measures and commitments to be agreed for each farm which aligns the future business development goals with the environmental needs at the landscape scale. The proposal agreed by all those involved was to develop discussion groups around particular themes: biodiversity (upland moors, pastures and ecological networks), water (rivers, blanket bog and land management) and carbon (upland oak woodland, hedgerows, wet woodland and the woodland economy). Membership of each group would be made up of statutory agencies, local conservation bodies and farmer/landowners who, through a facilitated process, will develop an action plan. Through this shared learning process, each group would identify the location of areas for enhancement, connectivity and new habitat creation, and the appropriate mechanisms to achieve these, in line with the land management needs and biodiversity strategies.

Through such a co-management approach, the policy process could serve the valuable goals of building social capital, institutional trust and thus a higher commitment to achieving policy objectives, among its key beneficiaries. This would offer more potential for policy learning within the various agencies, as well as supporting the objectives and values of local stakeholders. This approach thus differs from the more regulatory and incentive-driven approach currently in operation.

\section{Conclusions}

The proposal to use a co-management approach for a framework that would deliver both agricultural and environmental benefits, seems to be a requirement, because of the multiple local interests and multiple government agencies within a relatively small area. In order to meet multiple state and community objectives, a co-management approach is beneficial in securing long-lasting governance. As Carlsson and Berkes (2005:65) note, the approach should be seen as a 'continuous problem solving process ... involving extensive deliberation, negotiation and joint learning [original emphasis]. This finding is also reinforced by Reed (2008) and Leys and Vanclay (2011) who both identified the need for a greater use of participatory techniques in environmentally diverse and agriculturally marginal areas. The continuation of farming practices, skills, customs and traditions is 
explicitly supported in the policy statements and visions of most UK government agencies, including the environmental agencies (NE 2009; ENPA 2007; Carruthers et al. 2009).

The findings of this case study endorse a case for a new approach to economic and social regeneration in upland farming areas, working closely with the farming population as well as those other sectors and service providers with whom they interact most closely. This conclusion chimes well with other reviews, such as the Upland Communities Inquiry (CRC 2010), which has called for a more integrated and socially developed approach to policies for these areas, in future. It is worth noting that the GEMCONBIO project concludes that biodiversity conservation needs to be determined from local economic and social characteristics as well as local, national and international ecological needs. The policy recommendations include the need to 'recognise and respect customary institutions for natural resource management' and to 'foster alliances between local, traditional institutions governing natural resources and the governmental agencies in charge of conservation' (Simoncini et al. 2008). This is part of the call to recognise the localised connections between nature and society and mirrors other similar initiatives (Short et al. 2010).

This article supports the wider assimilation into policy of the policy recommendations of the GEMCONBIO project, to 'make contact with traditional structures' and involve them in both management activities and governance. However we need to be cautious about boarding what Kasperson (2006) calls the 'stakeholder involvement express' just because it is the trendiest train in the station. Ribot (2006) makes clear that stakeholder involvement has to be meaningful, since as with all decentralised approaches, they are 'only effective when there are mechanisms to represent local needs and aspirations in decision making'.

While many upland public goods and benefits are directly associated with land and land management, these are also connected with upland communities and the combination of land and people. The findings of this article point to a need for a more territoriallyfocused and multipurpose policy design and delivery for sustainable rural development in the English uplands (Ward and Lowe 2007). The model should offer an environmental scheme that meets the combined economic and environmental pressure of each distinctive upland area, perhaps more akin to a landscape-scale approach (Lawton 2010) which also understands the behaviours, motivations, and aspirations of farmers and landowners, which will create a synergy between pastoralism and wildlife. 


\section{Acknowledgements}

The authors would like to thank the European Commission, Exmoor National Park Authority (ENPA) and Natural England (NE) for providing the funding for this work and acknowledge the contribution made by lan Condliffe in undertaking some of the interviews. The research would not have been possible without the support and input of the farmers and other members of the local farming community in Exmoor through the face-to-face interviews and their participation so our thanks to them is substantial. The authors would like to thank the anonymous reviewers for their helpful and informative comments. All errors remain the responsibility of the authors.

\section{Author details}

${ }^{1}$ Countryside and Community Research Institute, University of Gloucestershire, Oxstalls Campus, Gloucester GL2 9HW, United Kingdom. ${ }^{2}$ Professor of Rural Policy, Countryside and Community Research Institute, University of Gloucestershire, Oxstalls Campus, Gloucester GL2 9HW, United Kingdom.

Received: 2 December 2011 Accepted: 29 March 2012

Published: 28 September 2012

\section{References}

Baldock, David, Janet Dwyer and Jose M Sumpsi-Vinas. 2002. Environmental Integration and the CAP. Brussels: Commission of the European Communities

Berkes, Fikret, J Colding, and C Folke. 2000. Rediscovery of traditional ecological knowledge as adaptive management. Ecological Applications 10(5):1251-1262.

Boatman, N, P Gaskell, C Short, H Parry, N Jones, S Bishop, J Mills, and J Dwyer. 2008. A Review of Environmental Benefits supplied by Agri-Environment Schemes, Report to the Land Use Policy Group by the Central Science Laboratory and Countryside and Community Research Institute. London: Natural England.

Carlsson Lars and Fikret Berkes. 2005. Co-management: concepts and methodological implications. Journal of Environmental Management 75: 65-76.

Carruthers, P, N Thomson, T Carroll, S Webster, A Harper, and I Soane. 2009. Developing the English Uplands: a report to the Commission for Rural Communities' Inquiry into the Future for England's Upland Communities. Cheltenham: CRC.

Commission for Rural Communities. 2008. An Inquiry into the Future for England's Upland Communities: Summary note. Cheltenham: CRC.

Commission for Rural Communities. 2010. The Future for England's Upland Communities - final report. Cheltenham: CRC

Condliffe, lan. 2009. Policy change in the uplands. In Drivers of Environmental Change in the Uplands, ed. Bonn Aletta, Allott Tim, Hubacek Klaus, and Stewart Jon, 59-90. London: Routledge.

Defra. 2011. June survey of agriculture and horticulture. http://www.defra.gov.uk/statistics/foodfarm/landuselivestock/ junesurvey/. Accessed 22 October 2011.

Defra Agricultural Change and Environment Observatory. 2009. Farm Practices Survey 2009 - Uplands And Other Less Favoured Areas (England) Attitudes To The Future. York: ACEO.

Dwyer, Janet. 2010. UK Land use futures: policy influence and challenges up to 2060. Land Use Policy. doi:10.1016/j. landusepol.2010.12.002.

English Nature. 1996. Upland Policy Review. Peterborough: English Nature.

English Nature. 2002. SSSI condition survey reports: upland habitats. Peterborough: English Nature.

Exmoor National Park. 2007. Exmoor National Park Management Plan. Dulverton: Exmoor National Park Authority.

Eriksson, Camilla. 2011. What is traditional pastoral farming? The politics of heritage and 'real values' in Swedish summer farms (fäbodbruk). Pastoralism: Research, Policy and Practice 1: 25.

Franks, J, D Harvey, and C Scott. 2008. Farm Business Survey 2006-2007 Hill Farming in England. Newcastle: Newcastle University Rural Business Research.

Gaskell, Peter, Nigel Boatman, Janet Dwyer, Jane Mills, Julie Ingram, Christopher Short and David Turley. 2008. Environmental Observatory update - the implications of the 2003 CAP reform for the environment in England. A report to Defra's Agricultural Change and Environment Observatory. (ACEO). Cheltenham: CCRI

Jacobson, C, K Hughey, W Allen, S Rixecker, and R Carter. 2009. Toward more reflexive use of adaptive management. Society and Natural Resources 22: 484-495.

Kasperson, R. 2006. Rerouting the stakeholder express. Global Environmental Change 16: 320-322.

Lawton, JH, Brotherton, PNM, Brown, VK, Elphick, C, Fitter, AH, Forshaw, J, Haddow, RW, Hilborne, S, Leafe, RN, Mace, GM, Southgate, MP, Sutherland, WJ, Tew, TE, Varley, J Wynne, GR, (2010). Making space for nature: a review of England's wildlife sites and ecological network. Report to Defra. Available at: http://www.defra.gov.uk/news/2010/09/ 24/nature-news/

Leys, A J, and J K Vanclay. 2011. Social learning: a knowledge and capacity building approach for adaptive comanagement of contested landscapes. Land Use Policy 28: 574-584.

Likens, G 1992. The ecosystem approach: its use and abuse. In Vol 3 Excellence in Ecology, ed. O Kinne. Germany Ecology Institute: Oldendor.

Lowe Philip and Neil Ward. 2007. Sustainable Rural Economies: Some Lessons from the English Experience. Sustainable Development 15: 307-317.

Millennium Ecosystem Assessment. 2005. Ecosystems and Human Well-being: Synthesis. Washington, DC: Island Press. National Ecosystem Assessment, 2011. UK National Ecosystem Assessment, Cambridge: UNEP-WCMC.http://uknea.unepwcmc.org. Accessed 22 October 2011.

England, N 2009. A Vision for the Uplands. Peterborough: Natural England.

Natural England. 2010. South West Uplands. Available at: http://www.naturalengland.org.uk/regions/south_west/ ourwork/southwestuplands/default.aspx, [accessed 22/10/2011].

Natural England. 2011. SSSI condition summary, Available at http:/www.sssi.naturalengland.org.uk/Special/sssi/report. cfm?category=N [Accessed 10/11/2011 
Nori, Silvia, and Gemini Michele. 2011. The Common Agricultural Policy vis-à-vis European pastoralists: principles and practices. Pastoralism: Research, Policy and Practice 1: 27.

Olsson, Per, Carl Folke, and Fikret Berkes. 2004. Adaptive co-management for building resilience in socio-ecological systems. Environmental Management 34(1):75-90.

Reed, M 2008. Stakeholder participation for environmental management: A literature review. Biological Conservation 141: 2417-2431.

Reed, M A Bonn, W Slee, N Beharry-Borg, J Birch, I Brown, T P Burt, D Chapman, P J Chapman, G D Clay, S J Cornell, E D G Fraser, J H Glass, J Holden, J A Hodgson, K Hubacel, B Irvine, N Jin, M J Kirkby, W E Kunin, O Moore, D Moseley, C Prell, M F Price, C H Quinn, S Redpath, C Reid, S Stagl, L C Stringer, M Termansen, S Thorp, W Towers, and F Worrall. 2009. The future of the uplands. Land Use Policy 26: 204-216.

Ribot, Jesse. 2006. Choose democracy: environmentalists' socio-political responsibility. Global Environmental Change 16:115-119.

Simoncini R G Borrini-Feyerabend and B Lassen. 2008. Policy Guidelines on Governance and Ecosystem Management for Biodiversity Conservation, report of the Governance and Ecosystem Management for the Conservation of Biology (GEMCONBIO) project, Final report, www.gemconbio.eu [Access on 10/10/11

Short, Christopher. 2008. The Traditional Commons of England and Wales in the Twenty-First Century: meeting new and old challenges, International Journal of the Commons - European Commons Special Issue, pp 192-221.

Short, C R Griffiths, and J Phelps. 2010. Inspiring and Enabling Local Communities: an integrated delivery model for Localism and the Environment. CCRI: Report to Farming and Wildlife Advisory Group and Natural England. Cheltenham.

Swales, V R Eaton, V Castan-Broto, R Deane, B Warmington, S Parker, and M Rayment. 2004. An assessment of the impacts of hill farming in England on the economic, environmental and social sustainability of the uplands and more widely. Defra: Report to Defra. London.

The World Bank. 1999. Report from the International Workshop on Community-Based Natural Resource Management (CBNRM), Washington, DC, 10-14 may 1998.

Turner, M K Robbins, and P Silcock. 2008. Hill Farming Systems in South West England: economic viability and the delivery of pubic goods. Exeter: University of Exeter.

doi:10.1186/2041-7136-2-13

Cite this article as: Short and Dwyer: Reconciling pastoral agriculture and nature conservation: developing a comanagement approach in the English uplands. Pastoralism: Research, Policy and Practice 2012 2:13.

\section{Submit your manuscript to a SpringerOpen ${ }^{\circ}$ journal and benefit from:}

- Convenient online submission

Rigorous peer review

- Immediate publication on acceptance

- Open access: articles freely available online

- High visibility within the field

Retaining the copyright to your article

Submit your next manuscript at $\boldsymbol{\nabla}$ springeropen.com 